Agnieszka Niezgoda

Poznań University of Economics

a.niezgoda@ue.poznan.pl

\title{
THE ROLE OF ENVIRONMENTAL KNOWLEDGE, ATTITUDES AND INITIATIVES IN THE DEVELOPMENT OF A TOURISM PRODUCT
}

\begin{abstract}
The article looks at environmental activities undertaken by the various stakeholders engaged in the development of a tourism product. Special attention is given to the impact of tourists' behaviour on tourist destination products and on future ecology-related actions of service providers. The meaning of environmental awareness is explained as well as its relationship with the concepts of sustainable tourism and eco-tourism. Some problems arising from demand for eco-products are discussed.
\end{abstract}

Key words: tourism product, environmental awareness, sustainable tourism.

\section{INTRODUCTION}

The tourism product is a complex proposition developed by multiple stakeholders who take advantage of the various tourist attractions of a destination to create a unique core of the product. This uniqueness decides about the product's attractiveness.

Progressive degradation of the environment has limited the number of valuable areas attractive for tourism. People can improve the quality of amenities and make a destination more accessible to tourists but they have only a limited ability to renew, enlarge or create new landscapes and natural tourist attractions. It is worthwhile, therefore, to examine the opportunities arising from environmental awareness on the part of both tourists and the stakeholders involved in the development of a tourism product.

The present article looks at environmentally responsible activities undertaken by the various stakeholders creating a tourism product. Special attention is given to the tourist whose behaviour impacts not only on the destination's existing product but also influences the character and quality of the product's components which will be used by future visitors, or even future generations of visitors.

We may put forward a thesis that environmental actions not only preserve the resources on which tourism development is based but also reinforce society's environmental awareness, a necessary precondition for the prevention of the environment's degradation. Ecological education is a two-way process: its purpose is to develop environmentally responsible attitudes but in turn provision of ecological education depends on the existence of such attitudes in the society.

\section{NATURE AND DEFINITION OF ENVIRONMENTAL AWARENESS}

In the late nineteen-sixties a growing awareness of the threats to the natural environment led to purposeful and organised actions aimed at preventing the process of environmental degradation. It is reflected in numerous initiatives undertaken at the time both internationally and on a local scale whose purpose was to recognise, control and curb further degradation of the natural environment. The efforts of the international community since then have resulted in legal regulations, political and economic decisions, technological solutions, and last but not least in the higher environmental awareness of societies.

A major landmark in environmental awareness was the publication in 1969 of the United Nations report on the Problems of Human Environment ('the U Thant Report') (BOHDANOWICZ 2008, p. 67). The report made the international community aware of the scarcity and fragility of natural resources, the growing degradation of the Earth's environment, and the existence of development barriers in the world.

An important event in environmental education was the Belgrade conference organised by UNESCO in 1975 which set out the goals for environmental instruction at different learning stages and in different educational systems. That programme was further developed by the Tbilisi Declaration issued by a joint conference of UNESCO and UNEP in 1977. The Declaration placed an obligation on UNESCO member states to include environmental education in school curricula and allocate adequate resources for this purpose (MICHAŁOWSKI 1994, pp. 22-23). 
Environmental awareness is an integral part of social awareness, understood as an aggregate of ideas, concepts, convictions, opinions, and attitudes shared by entire social groups (such as nations, classes, and religious or professional groups), institutionalised and solidified in historically developed civilisations (BOHDANOWICZ 2008, p. 68).

The notion of environmental awareness can be explored from both descriptive (what it is) and prescriptive (what it should be) perspectives. A popular approach encountered in the literature is to define a broad and narrow meaning of the notion (GóRKA, POSKROBKO, RADECKI 2001). In a broader sense environmental awareness is defined as a set of ideas, values and opinions about the natural environment as a living place for humans (societies), shared by specific groups in a given historic period. In a narrower sense environmental awareness is construed as the state of knowledge, concepts and views on the role of the environment in human life, the impact of man on the environment, the extent of environmental degradation and depletion of natural resources, existing and potential threats, and protection of the environment including the state of knowledge about the ways and instruments for controlling the use of environmental resources. The latter approach is considered more practical. BURGER (1996) proposes another practical definition describing environmental awareness as a set of facts and convictions about the natural environment and the recognition of a relationship between the state of the natural environment and human quality of life.

A higher level of environmental awareness is needed to curb wasteful exploitation of resources in many parts of the world. As KASPRZYK (2006) reports, irresponsible exploitation of the environment is common in places where communities do not participate in the development of local policy. Local communities, their representative bodies, non-governmental organisations and expert groups should all have a say in the setting of local priorities, allocation of resources and spatial planning.

Leaving aside definitions we may conclude that environmental awareness is:

- a subjective phenomenon that should be evaluated from the individual's perspective;

- a complex process which depends on the degree of social acceptance of ideas and moral standards, and on the knowledge of impacts of various forms of economic and social activity on the environment.

We should note that moral norms are the effect of traditional attitudes towards the environment whereas knowledge is the effect of education and direct observations. Education is needed to promote responsible use of the nature's resources based on:
- understanding of and sensitivity to the natural environment;

- respect for the natural environment and motivation to improve or preserve its quality;

- ability to recognise ecological problems and participate in their solution.

Citing MichAŁOWSKI (1994, p. 37) we may say that '[...] protection and development of the environment relates to the activities and attitudes of man in the areas of politics, economy and social life; it also concerns interpersonal relations, and attitudes towards the older people, the weak and vulnerable. This process of educating the society aims at creating conscious civic attitudes but it also depends on the existence of such attitudes'.

The development of pro-ecology attitudes is a twostage process: first a system of values is created and afterwards such a system of values, accepted by societies and individuals, influences people's behaviour. The environmental awareness and the resulting proactive behaviour concern many aspects of human life, including leisure activities and tourism. Inappropriate behaviour of tourists and tourism stakeholders towards the environment, be it due to lack of environmental awareness or pure neglect, leads to its degradation. Often the differences in rational behaviour of groups and individuals arise from differences in priorities set by those groups and individuals as in the short term the cost of environmental protection requires societies to forfeit some of their material welfare.

Environmental awareness is an issue requiring a broad humanistic understanding of the role of man in the natural environment rather than a purely pragmatic and technocratic approach. A humanistic approach assumes the central role of man not only by virtue of his needs but above all because of the consequences of his actions and his responsibility for the state of the environment. A direct consequence of such approach is the extension of planning time horizons: a long-term perspective towards the environment takes precedence over short-term objectives.

Literature identifies two kinds of environmental movements (MiCHAŁOWSKI 1994, p. 40). The first one represents a traditional conservational approach, focusing on the issues of environmental degradation and related threats to human existence. The other movement perceives the human surroundings through the prism of cultural, humanistic and civilisation values. 


\section{PRINCIPLES OF TOURISM PRODUCT DEVELOPMENT IN THE LIGHT OF SUSTAINABLE TOURISM AND ECOTOURISM CONCEPTS}

The fundamental premise of sustainable development and the related concept of sustainable tourism is the preservation of natural resources for future generations. The Federation of National Parks and Protected Areas of Europe defines sustainable tourism as 'any form of tourism development, tourism activity and tourism management that maintains the ecological, social and economic integrity of areas, and preserves in unaltered state the natural and cultural resources of these areas' (ZARĘBA 2000, p. 43). The ultimate goal of the sustainable tourism concept is, therefore, the achievement of harmony between the needs of tourists, the natural environment and local communities.

The objectives of sustainable tourism at destination level can be sorted into three groups, analogous to the aims of sustainable development:

- environmental objectives: preservation of natural resources for tourist purposes; reduction of environmental pollution and degradation caused by tourism;

- economic objectives: host communities material welfare; the maintenance and optimal usage of tourism infrastructure;

- social objectives: opportunities for gainful employment in the tourism sector; recreation opportunities for both visitors and host communities; protection of cultural identity of local communities; increased community participation in local tourism policy.

The three types of objectives are interrelated, with sustainable development of a destination being the ultimate goal. It would be wrong, therefore, to analyse the objectives separately without showing how they complement each other. However, interactions and conflicts between particular objectives can be considered in detail only when specific case studies are analysed.

A concept related to sustainable tourism is ecotourism, understood as a form of active exploration of areas characterised by outstanding natural and cultural qualities, a form of tourism which has no negative impact on natural ecosystems or cultural identities of local communities, and finally generates financial resources for the protection and preservation of tourism areas (ZARĘBA 2000, p. 47, NIEZGODA 2006, p. 35). Ecotourism is regarded as the 'purest' form of environmentally-friendly travelling (WEAVER 2001, p. 15). A development imperative of ecotourism is the existence of the highest quality natural areas. In the literature ecotourism is sometimes considered synonymous with sustainable tourism, although such an approach is imprecise since ecotourism can only be regarded as the 'hard core' of sustainable tourism (NIEZGODA 2006).

Sustainable tourism development requires that all stakeholders involved in the development of a tourism product realise the impacts of tourism on the environment and know how to control these impacts by implementing the necessary changes and improvements. In practice, the environmental awareness of stakeholders should be translated into pro-ecology policies, i.e. policies consistent with the objectives of environmental protection. In the process of tourism product development this consistency should be reflected in:

- rational use of resources (saving of water, energy, etc);

- knowledge and observance of environmental protection principles laid down in acts of law;

- readiness to participate in environmental initiatives undertaken by other stakeholders and organisations;

- projection of responsibility and care about the state of the natural environment.

All such actions require the involvement and collaboration of the stakeholders. The tourism product is a perfect example of a situation where failure to act on the part of one actor (service provider) can foil the efforts of other stakeholders. For instance, by segregating waste both the hotel operator and the tourist undertake an environmentally-friendly action. But if the local authority fails to put in place a waste recycling scheme then such action is rendered ineffective.

\section{ECOLOGICAL DETERMINANTS OF TOURIST PURCHASING BEHAVIOUR}

Tourist purchasing behaviour is part of a complex multi-phase process resulting in the needs and desires of the tourist being concretised in specific characteristics and qualities of a purchased product or service. With a composite product, such as the tourism product, the buyer may look for different qualities in the various elements of the purchased good or service. An unsatisfied need triggers the consumer decisionmaking process involving multiple considerations such as disposable income of the consumer, availability of information about the product or the valuefor-money issue.

Many commentators argue that the average consumer does not regard environmental issues as the most important criterion in planning a holiday. Even ardent proponents of nature tourism, the most environmentally-aware group of travellers, are first of all consumers and their desire to get as close as possible to the place of interest may often take pre- 
cedence over environmental considerations (MAJEWSKI 2008, p. 193). Nevertheless, the problems of environmental protection are increasingly coming to the fore. Tourist-consumers begin to understand that their conscious actions (or conscious failure to act) affect other spheres of social and economic life (NIEMCZYK 2008, p 193).

In the purchase decision-making process, environmental issues may collide with other selection criteria applied by the tourist-consumer. Such conflicts of interest, or 'collisions' (JEDLINSKA 2004, p. 38), are common in the process of satisfying needs. So if a tourist were to buy an ecology friendly product or service his or her environmental awareness would have to take precedence over other considerations such as routine, comfort or ease of access to goods and services.

Market research by PONDEL (2007) cites a number of 'green consumer' typologies. By personality-type consumers can be divided into:

- traditionally-oriented - the least caring about environmental issues, proponents of private property, economic growth and material welfare;

- outward-oriented - concerned about the future of society;

- inward-oriented - concerned mainly about the impact of the environment on human health.

Each of the three types of consumers may have a motivation for eco-friendly behaviour. 'Traditional' consumers, pursuing and attaining the goal of higher living standards, are ultimately motivated by higherorder needs. According to Maslow's hierarchy of needs, once a lower need has been satisfied a higher order need becomes a motivator, therefore having satisfied their material ambitions traditional consumers may look for esteem and self-actualisation in the pursuit of social and environmental goals.

The outward-oriented tourist-consumer is concerned about tourism impacts on destinations. Such a traveller might be an advocate of KRIPENDORF's (1982) 'soft tourism', a form of tourism which builds close ties between visitors and local communities. The outward-oriented tourist may prefer to purchase local produce over globally sourced imports, and may want to have a positive influence on local people.

Inward-oriented consumers attach great importance to the effect of the environment on their health. Such self-centred consumers are likely to choose attractive, unspoilt destinations but it does not mean that they overly care about the social or environmental issues of the visited places.

It is somewhat disturbing that while people seem to appreciate the effects of environmental initiatives they are frequently not inclined to change their own ways and make small sacrifices for the good of the environment.
The above considerations have led us to propose the following determinants of environmentallymotivated tourist purchasing decisions:

1. Personal motivations - focusing on health concerns, and the quality and safety of vacationing.

2. Conformist motivations - adhering to contemporary eco-fashions and eco-trends, accepting and observing existing legal regulations.

3. Ideological motivations - arising from genuine understanding and concern about the present and future condition of natural and social environments, and expressing readiness to act preventively to forestall further environmental degradation.

Tourists whose purchasing decisions are environmentally motivated have to realise that their choices may compromise other objectives and benefits, for example:

- staying at an eco-lodge or purchasing local products and services can be more expensive than choosing conventional accommodation and massproduced goods;

- eco-products and eco-services can have inferior utility and be less convenient (e.g. using public transport to get to a holiday destination can be more troublesome than using one's own car);

- eco-products can be less attractive than their conventional equivalents, e.g. bathrooms at eco-lodgings may be more modestly arranged compared with those provided in alternative accommodation facilities;

- environmentally motivated behaviour can be seen as odd by those who prefer ostentatious consumption, e.g. a person using public transport, not indulging in shopping sprees, or buying only local produce may be looked upon by others as someone who cannot afford a 'better holiday'.

In order to overcome such dilemmas, environmentally motivated tourists must have strong convictions about the rightness of their decisions and should not succumb to inner doubts that their actions might be marginal and ineffective.

Awareness about the impact of the environment on human health and quality of life, although not sufficient without actions, could become a starting point for further exploration of the issue and ultimate translation of the knowledge into environmentallyfriendly behaviour. Consumer environmental awareness can thus become a factor in:

- routine activities at home and at work;

- buying decisions;

- leisure time activities;

- holiday and travel choices.

With a society's advanced level of environmental awareness a new type of consumer emerges. This new consumer is prepared to change his or her lifestyle and consumption model to protect the environment. Such a consumer/tourist segregates household waste, saves 
energy and water, buys eco-friendly products, uses public transport leaving the private car at home or at a car park, and walks or rides only along designated tourist trails. The environmentally motivated tourist shows his or her authentic concern about the environment by applying the same standards at home and on holiday, saving water and energy on vacation just as they would at home even though such behaviour might not translate into immediate financial savings. The environmentally motivated tourist will encourage other holiday-makers to behave in an environmentally-friendly manner and will suggest to service providers that they meet environmental requirements in their offers. In a competitive, free market economy consumer needs and requirements should be taken as a starting point for developing sales offers. Marketoriented producers and service providers may have no choice but to take account of suggestions put forward by environmentally motivated consumers.

\section{ENVIRONMENTAL CONSIDERATIONS IN TOURISM PRODUCT DEVELOPMENT}

As has been stated, the complex tourism product needs a collaboration of many stakeholders. At a destination level these might be tourism firms (hotel operators, restaurateurs, and travel agencies), local authorities, tourism organisations, promotion agencies, and the local community which provides the workforce for the tourism industry and - through its culture and attitudes towards visitors - creates the unique atmosphere of the place. To make the collaboration effective in providing an eco-friendly product the level of environmental knowledge and awareness among all stakeholders should be equally high (BYRD 2007, p. 8).

Tourism firms can introduce and adhere to a variety of eco-friendly practices, such as efficient use of office supplies or avoidance of food wastage. They can also encourage their customers and suppliers to do the same. Other examples of environmentally-friendly practices include:

- using eco-friendly equipment and cooperating with environmentally responsible suppliers;

- training and motivating employees to adopt an environmentally responsible behaviour;

- employing environmentalists to develop and implement ecological programmes for tourists.

To prevent congestion and make sure that a destination's carrying capacity is not exceeded, travel agencies can collaborate on 'splitting' the tourist 'traffic' to less crowded destinations.

A special group of service providers are hotel companies. More and more tourists attach importance to environmental issues and expect the same from hotel operators. Such tourists are likely to choose accommodation that meets strict environmental standards (MAJEWSKI 2003, p. 95). A survey conducted on a sample of 5000 tourists across Europe has shown that more than half the respondents believe that hotels should use sustainable energy sources (wind, solar or hydro) (www.dziennikturystyczny.pl). Almost onethird $(29 \%)$ of the Europeans would book an ecofriendly hotel if they had a choice. Interestingly, more than three-quarters of respondents $(76 \%)$ are more concerned about their impact on the environment while they are on holiday than when they are at home: $88 \%$ of respondents turn the light off when leaving a hotel room, $63 \%$ use a hotel towel more than once. Almost half the respondents (48\%) believe that hotel bathrooms should install low flush toilets to save water.

Eco-friendly practices and environmental initiatives undertaken by tourism firms have become important instruments of public relations and promotion. The environmentally friendly image of tourism suppliers may attract tourists to a destination and contributes to the destination's competitive advantage in the market. In many cases the eco-friendly message is genuine and indeed companies apply policies and practices aimed at minimising the negative impacts of tourism on the environment. Alas, there are operators who only pay lip service to environmental issues in order to gain advantage over their competitors (CZERWIŃSKA 2009, p. 201).

Local authorities, as initiators and coordinators of actions, play a very important role in the development of tourism products. Regional and local councils provide and operate environmental facilities, manage protected areas, and run educational and promotional programmes to raise the level of environmental awareness in the society.

Local government environmental management operations include:

- providing and operating waste and water treatments facilities;

- controlling noise pollution;

- designating and managing protected areas: beauty spots, nature reserves, country parks, national parks, and spas;

- protecting outstanding monuments of nature, and species of fauna and flora.

Local government environmental initiatives in the management of tourism include:

- monitoring the impacts of tourism on the environment;

- monitoring and controlling tourism flows to prevent overcrowding and breach of carrying capacities;

- providing or supporting eco-friendly means of transport in areas of heavy traffic; 
- developing environmental infrastructures and services in protected areas and their immediate surroundings;

- supporting green forms of tourism;

- providing educational programmes for residents, tourists and entrepreneurs.

Green projects undertaken by local authorities contribute to the preservation of attractive areas and thus support the competitiveness of entire regions.

Environmental education schemes will advance awareness, knowledge and skills among all stakeholders involved in the development of a tourism product. Instruction should be addressed to both professionals and the community and it should make clear that:

- problems of natural and social environments are among the most important issues of the contemporary world;

- tourists, tourism organisers, and service providers should develop appropriate attitudes towards problems of the environment;

- tourism has both positive and negative impacts (direct or indirect) on the environment and community;

- environmental awareness should be translated into proactive policies and initiatives.

Local authorities can set environmental standards for enterprises, including tourism firms (e.g. by setting guidelines for the segregation of solid waste and reduction of harmful emissions), and control development of tourism accommodation, services and transport infrastructures through spatial planning and tax incentives. Environmental education can be provided in the form of training courses, competitions, conferences, public messages (notice boards, local newspapers, bulletins), and provision of educational walkways.

In addition, promotional agencies can play a role in environmental education through campaigns addressed to tourists, local communities, service providers and tourism organisers. For example, promotional messages addressed to foreign visitors to Poland might highlight the uniqueness of the ecosystems of many Polish regions.

An environmentally aware and knowledgeable local community plays a vital role in the protection and preservation of natural attractions that constitute a source of a destination's competitive advantage. In turn a high-quality, sustainable environment has a positive effect on the communities' quality of life, making people stay in the locality and put their energy into local development. Ultimately this has a positive impact on the quality and attractiveness of the destination's tourism product, as satisfied residents create the atmosphere of the place, so much appreciated by visitors (NIEZGODA 2006). We may therefore agree with PENDER and SHARPLEY (2008) that
'The local community should be viewed not as [...] disadvantageous to environmental management but as architects of their own development. A local community's cultural attitudes towards the environment should be recognised and harnessed'.

This view finds support in a study conducted by GRÖNHOLM (2010). It compared the attitudes of permanent and seasonal residents of the Turku Archipelago (Finland) towards government policies. Among the examined issues were environmental policies. It transpired that both permanent and seasonal residents resisted economic development in their area and preferred the preservation of their 'little paradise' for rest and recreation purposes. WILLET (2010) in her study of the environmental attitudes of tourists and residents in Cornwall obtained somewhat different results: tourists preferred the preservation of the idyllic landscape whereas the residents would like a more dynamic economic development of the area.

An important issue is the motivation behind environmentally-friendly behaviour. While it is easier to act in an environmentally-friendly manner if such actions bring some immediate tangible benefits (such as lower power and water bills), environ mental actions which do not guarantee such benefits require a genuine environmental awareness, a broad humanistic approach, and a true concern about the effects of environmental degradation for future generations (NIEZGODA 2011). Ultimately, the proactive environmental attitudes of host communities will contribute to:

- a clean environment rendering the destination more attractive to tourists

- a better quality of life for the local population, in turn reflected in the 'atmosphere of the place' which attracts new tourists and/or makes visitors return to the destination in the future.

\section{SUMMARY}

With increased knowledge about threats to the environment, and given an urgent need for broad measures to protect ecosystems, environmental awareness has become an important issue in global, national and local policies. Protection of the environment concerns governments at all levels, industry, and individuals equally. The discussion in this article has shown that there are several environmentally related issues specific to the tourism product:

1. All stakeholders collaborating on the development of a complex, multidisciplinary tourism product need to display an equally high level of environmental knowledge and awareness. 
2. Environmentally proactive attitudes shown by tourism area stakeholders are not only essential to preserve the valuable core of the tourism product but also engender a high level of environmental awareness in other tourism market participants.

In discussing environmental consciousness we should be aware that not all eco-friendly attitudes and actions are genuine, selfless or even effective. A common problem is the misuse and abuse of ecolabels on the part of dishonest producers exploiting environmentally related health concerns and the resulting demand for green products. The popularity of eco-friendly products often leads to misconceptions in the ideas of environmental awareness and proactive behaviour. Many consumers believe that by purchasing eco-products they show their environmental responsibility. They may not be aware, however, that in Poland many firms 'award' themselves eco-labels without adhering to any green manufacturing criteria (BOHDANOWICZ 2008, p. 67).

Therefore in developing a truly eco-friendly tourist offer we should take account of the following problems:

- there is widespread abuse in the market of ecofriendly product names and promotional slogans

- some consumers may be guided by stereotypes, biases or negative associations related to eco-friendly products (e.g. they may think that such products are plain or more expensive)

- there is 'information noise' in the market caused by a multiplicity of 'eco-labels' and unclear criteria for awarding such labels

- the ubiquitous eco-labels and eco-slogans in tourism may confuse consumers who base their purchasing decisions on genuine environmental criteria.

Despite the many problems and misconceptions we should recognise and appreciate the growing popularity of environmental issues in society and specifically in the tourism market. Developing ecofriendly products and informing the market about their environmentally responsible characteristics in many ways raises the level of ecological awareness in potential buyers and other market participants.

\section{BIBLIOGRAPHY}

BOHDANOWICZ, P., 2008, Turystyka a świadomość ekologiczna, Wyd. Adam Marszałek, Toruń.

BURGER, T., 1996, Uwagi o świadomości ekologicznej, ‘Przegląd Powszechny', nr 12.
BYRD, E.T., 2007, Stakeholders in Sustainable Tourism Development and their Roles: Applying Stakeholder Theory to Sustainable Tourism Development, 'Tourism Review', vol. 62, No. 2, pp. 613.

CZERWIŃSKA, M., 2009, Znaczenie marketingu ekologicznego w turystyce, [in:] Marketing w rozwoju turystyki, J. Chotkowski (ed.), Wyd. Politechniki Koszalińskiej, Koszalin, pp. 198-208.

GÓRKA, K., POSKROBKO, B., RADECKI, W., 2001, Ochrona środowiska. Problemy społeczne, ekonomiczne i prawne, Wyd. PWE, Warszawa.

GRÖNHOLM, S., 2010, Perceptions of rural needs and policy - the case of the archipelago of Turku, 'Regions', No. 278, Regional Studies Association, pp. 12-14.

JEDLIŃSKA, M., 2004, Proekologiczne potrzeby konsumentów. Marketing ekologiczny, S. Zaremba (ed.), Wyd. Akademii Ekonomicznej we Wrocławiu, Wrocław, pp. 35-55.

KASPRZYK, K., 2006, Wielkopolski Park Narodowy - próba ochrony przestrzeni publicznej w aspekcie zrównoważonego rozwoju, [in:] Wspótpraca poptaca, K. Kasprzak, M. Ornoch-Tabędzka (ed.), Bogucki Wydawnictwo Naukowe, Poznań, pp. 7-26.

KRIPPENDORF, J., 1982, Towards New Tourism Policies: Importance of Environmental and Socio-Cultural Factors, "Tourism Management', No. 3.

MAJEWSKI, J., 2003, Turystyka wiejska i rozwój lokalny, Fundacja 'Edukacja dla Demokracji', Warszawa.

MAJEWSKI, J., 2008, Czy turystyka wiejska powinna być zrównoważona?, [in:] Zrównoważony rozwój turystyki, S. Wodejko (ed.), Szkoła Główna Handlowa, Warszawa, pp. 185-198.

MiCHAŁOWSKI, S., 1994, Problem świadomości ekologicznej $i$ wychowania ekologicznego w Polsce na tle doświadczeń edukacji ekologicznej w RFN, [in:] Ekologiczne wyzwania Polski, Wyd. Kopia, Warszawa, pp. 21-75.

NIEMCZYK, A., 2008, Turysta wobec koncepcji zrównoważonego rozwoju, [in:] Zrównoważony rozwój turystyki, S. Wodejko (ed.), Szkoła Główna Handlowa, Warszawa 2008, pp. 71-82.

NiEZGODA, A., 2006, Obszar recepcji turystycznej w warunkach rozwoju zrównoważonego, Wyd. Akademii Ekonomicznej w Poznaniu, Poznań.

NIEZGODA, A., 2010, Ekologiczne uwarunkowania zachowań nabywczych w turystyce, [in:] Potencjat turystyczny. Zagadnienia przestrzenne, B. Meyer (ed.), Zeszyty Naukowe, nr 590, Uniwersytet Szczeciński, pp. 643-652.

NiEZGODA, A., 2011, A survey of Poznań residents on tourism development in the city, [in:] Determinants of tourism development in urban destinations and methods of tourism measurement, G. Gołembski (ed.), Poznań University of Economics Press, Poznań, pp. 99-132.

PENDER, L., SHARPLEY, R. (ed.), 2008, Zarzadzanie turystyka, PWE, Warszawa.

PONDEL, H., 2007, Wykorzystanie koncepcji ekomarketingu w rynkowej walce o klienta. Zarzadzanie i marketing, Zeszyty Naukowe Wyższej Szkoły Humanistyczno-Menadżerskiej 'Millenium', Gniezno, pp. 45-60.

WEAVER, D., 2001, Ecotourism, John Wiley \& Sons, Malbourne.

WILLET, J., CORNWALL, 2010, The experience economy and the tourist return, 'Regions', No. 278, Regional Studies Association, pp. 19-21.

ZARĘBA, D., 2000, Ekoturystyka, Wyd. Naukowe PWN, Warszawa.

www.dziennikturystyczny.pl, pobrano 22.11.2009. 